\title{
Pheromone monitoring of harmful Lepidoptera present in Bistrita area in apple and plum orchards
}

\author{
S.D. Rosu-Mares ${ }^{1 *}$, M. Pojar Feneșan ${ }^{2}$, I. Ciotlaus ${ }^{2}$, A. Balea ${ }^{2}$ and A. Andreica² \\ 1Fruit Research and Development Station Bistrita, Romania.
}

2 Babes-Bolyai” University - “Raluca Ripan”, Institute for Research in Chemistry

Corresponding author email: rmsd_smery@yahoo.com

\begin{abstract}
This study investigates the Lepidoptera order representatives among the pests present in apple and plum orchards in the central and northern part of the Bistrita region. This study aimed to find out which ones of the Lepidoptera pests are present in the area and what is their population density. By field trapping of moths and leaf miners, in 2021 we are presenting an up-to-date situation of the main damaging species from the Lepidoptera order. Pheromone traps with attractants for seven species were placed in four locations in apple and plum orchards. The monitored species were: Cydia pomonella, Hedya nubiferana, Spilonota ocellana, Phyllonorycter blancardella, and Leucoptera scitella in the apple orchards. In plum orchards, we placed lures for Cydia funebrana and Grapholita molesta. Our data confirm some of the previous known facts about the flight patterns of Cydia pomonella, Phyllonorycter blancardella, Leucoptera scitella, Cydia funebrana and Grapholita molesta but show a longer flight period. Defoliators such as Hedya nubiferana and Spilonota ocellana are also present and could become a threat in the next years.
\end{abstract}

Keywords: codling moth, spotted tentiform leaf miner, pear leaf blister moth, red plum maggot, oriental fruit moth, defoliators.

\section{INTRODUCTION}

Bistrita region is a traditional area for fruit growing, apple and plum being the most frequent species in this area's orchards. The growers in Bistrita area confronted, over time, the threat of many pests and among them, members of the Lepidoptera order had always been of great economic importance. In the last years, changes appeared in the spectrum of pests both in apple and plum orchards due to climate change and the ban of highly efficient insecticides.

A study performed in Sweden, in the first half of this decade, revealed that the damage caused to the apple fruits by other Tortricidae moths (leaf rollers and defoliators) was higher than the damage caused by the codling moth (Sjoberg et al., 2015).

Similar trends have been observed by growers in the last years in the Bistrita region, and at the same time, multiannual data show an increase in Cydia pomonella moths caught, as well as extended flight periods when compared with older data (Rosu-Mares et al., 2020).

Published data on members of the Lepidoptera order, in the Bistrita region, indicate that the species Cydia pomonella, Phyllonorycter blancardella, Leucoptera scitella, Cydia funebrana are present in this area. The data regarding the species listed above are mostly limited to the data from the orchards belonging to Fruit Research \& Development Station Bistrita. The 
present study aims to expand the investigated area both around the municipality of Bistrita and in the northern mountainous area of the county. One of the orchards being located in Maieru, $54 \mathrm{~km}$ from Bistrita to the north-east.

The use of pheromones had a great impact for monitoring the flight of the adult males. This allowed more precise use of the insecticides in conventional control programs and implementation of the "attract and kill", mass trapping (Ghizdavu et al., 1987) or mating disruption as methods of controlling pests in Integrated Pest Management and biological control of the harmful Lepidoptera. Recent studies performed in treated apple orchards show good results in reducing the number of insecticide treatments when combined with mating disruption by pheromones (Sumedrea et al., 2015). Pesticide resistance in pests is one of the problems that could be solved in some species by alternating seasons of conventional control with seasons of pheromonal mating disruption. Studies performed in Canada (Smirle et al., 1998) indicate that the resistance developed by Lepidoptera species can be reversed when the resistant population is no longer exposed to that insecticide. This is a relevant aspect that makes the use of pheromones in mating disruption or other biological methods of control, very important. The period of the 70s and $80 \mathrm{~s}$ of the last century brought important advances in the discovery of chemical compounds synthesized by females of many species of insects and which act as attractive pheromones for males.

The identification of (8E,10E)-8,10-dodecadien-1-ol (Buser and Arn, 1975) as a specific sex pheromone of species Cydia pomonella has been an important step towards the better understanding of this pest's flying patterns. After the synthesis of the pheromone for Cydia funebrana was performed (Granges and Baggiolini, 1971), the flight of the moth has been tracked and served to improve the timing of treatments in commercial orchards. Mating disruption techniques have also been used for red plum maggot control as an alternative to insecticide sprays (Arn et al., 1976). For Grapholita molesta many variants of lures were produced since 1969 when Roelofs et all identified (Z)-8-dodecenyl acetate as a major component of the specific pheromone. The composition for lures that attract Phyllonoricter blancardella males is known since 1977 when Roelofs et al. (1977) stated that (E)-10Dodecenyl acetate is the sex pheromone for the spotted tentiform leafminer and even if there were studies that identified other compounds in signalling females (Mozûraitis et al., 1999) still the first variant proved to attract males. Sex pheromones emitted by females to attract the males, currently used as lures are an E8, E10-dodecadien-1-yl acetate and Z8dodecen-1-yl acetate mixture (Roelofs and Brown, 1982) for monitoring Hedya nubiferana and compound Z8-tetradecen-1-yl acetate proposed by McBrien et al. (1992), for Spilonota ocellana.

Francke et al. (1987), identified the specific pheromone for the pear leaf blister moth that is also a component of other Lyonetiidae species.

Pheromone synthesis continues to be improved and was also studied and performed in Romania for numerous Lepidoptera species such as: Leucoptera scitella (Ciocan-Tarta et al., 1998), Phyllonoricter blancardella (Gânscă et al., 2001; Vasian et al., 2013), Grapholita molesta, Cydia funebrana (Ciotlăuș et al., 2017) and Hedya nubiferana.

This study aimed to find out what is the spread area and what is the density of the populations of the above-mentioned species so that the mating disruption by using pheromones can be proposed as biological control method for the studied locations.

\section{MATERIALS AND METHODS}

The study was conducted in the central and northern regions of Bistrita-Nasaud County in 4 apple and 4 plum orchards (Location 1: $47^{\circ} 16^{\prime} \mathrm{N} 24^{\circ} 39^{\prime} \mathrm{E}$; location 2: $47^{\circ} 9^{\prime} \mathrm{N} 24^{\circ} 23^{\prime} \mathrm{E}$, location 3: $47^{\circ} 24^{\prime} \mathrm{N} 24^{\circ} 45^{\prime} \mathrm{E}$; location 4: $47^{\circ} 23^{\prime} \mathrm{N} 24^{\circ} 45^{\prime} \mathrm{E}$ ) in the years 2019-2021. The 
elevation of these for locations is: $345 \mathrm{~m}$ in location $1.358 \mathrm{~m}$ in location $2.352 \mathrm{~m}$ in location 3 and $518 \mathrm{~m}$ in location 4 . Pheromone traps were placed in each orchard and male captures were recorded weekly from the last decade of April to September. All orchards are old, over twenty years of age and a minimum number of conventional phytosanitary treatments were made. The phytosanitary treatments consisted in the application of the winter sprays with mineral oils against the eggs and hibernating larvae of the pests, respectively with copperbased substances in winter and spring in order to fight the fungal and bacterial diseases. We used attractants for Cydia pomonella. Hedya nubiferana, Spilonota ocellana, Phyllonorycter blancardella, and Leucoptera scitella in the apple orchards. In plum orchards, we placed lures for Cydia funebrana and Grapholita molesta. The distance between different traps has been over $50 \mathrm{~m}$ to avoid interferences between lures.

Data was grouped on seven days intervals and performed graphical representation of the flying curves for the species that presented relevant activity, using Microsoft Excel tools.

Data regarding the number of moths caught in the four orchards were statistically analyzed by calculating the coefficient of variance for each of the species in the four locations and by making correlations between the number of male moths captured and meteorological factors. The correlation between variables was considered using the standard correlation coefficient $(r)$ significance: $r<0,1$ - no correlation; $r=0.1-0.39$ - weak correlation; $r=0.4-0.69$ - moderate correlation; $r=0.7-0.89$ - strong correlation and $r=0.9-1$-very strong correlation. The synthesis of the pheromones was achieved in Natural Products Laboratory from "Raluca Ripan" Institute for Research in Chemistry Cluj-Napoca. The composition of the lures for each trap is presented in Table 1.

Table 1. Composition of pheromones used in field monitoring of Lepidoptera in 2021 proportion of substances.

\begin{tabular}{|l|c|}
\hline \multicolumn{1}{|c|}{ Species } & Lure composition \\
\hline Cydia pomonella & E8, E10-dodecadien-1-ol (100\%) \\
\hline Cydia funebrana & (Z)-8-dodecen-1-yl acetate :(E)-8- dodecen-1-yl acetate= 96.5: 3.5 \\
\hline Grapholita molesta & (Z)-8-dodecen-1-yl acetate:(E)-8- dodecen-1-yl acetate: dodecan-1-ol= \\
& $\begin{array}{c}90: 8: 2 \\
\end{array}$ \\
\hline Hedya nubiferana & (E8, E10)-Dodecadienyl acetate: (Z)-8-Dodecenyl acetate= 60:40 \\
\hline Spilonota ocellana & Z-8-tetradecenyl acetate (100\%) \\
\hline $\begin{array}{l}\text { Phyllonoricter } \\
\text { blancardella }\end{array}$ & (E)-10-Dodecenyl acetate (100\%) \\
\hline Leucoptera scitella & 5.9-Dimethylheptadecane (100\%) \\
\hline
\end{tabular}

\section{RESULTS AND DISCUSSIONS}

Cydia pomonella showed an interesting distribution of the males caught on the sticky traps. While on location 4 the two peaks indicate the two generations of the moth, in the other three locations there, are four peaks through the summer. It can be observed that although the flight level decrease at the end of the season it continued until the fourth of October. (Figure 1). We analyzed the existing data on average humidity, maximum humidity and the amount of precipitation in the intervals between two trap readings, for the year 2021. This distribution was influenced by the meteorological conditions in May, June and July 2021 when there were several periods of rainy days. These periods overlap the drop in the number of moths caught. The number of male moths caught on traps was high all summer, mostly over the economical threshold of five individuals/trap/week reaching a maximum of 72 in location 2 . This is most probably due to the lack of insecticide treatments in the studied orchards. The data indicate 
the hight population density of this pest that requires control in the future. The results obtained by us in 2021 confirm the recent previous data (Rosu-Mares et al., 2020) regarding the extension of the flight period until the first decade of October.

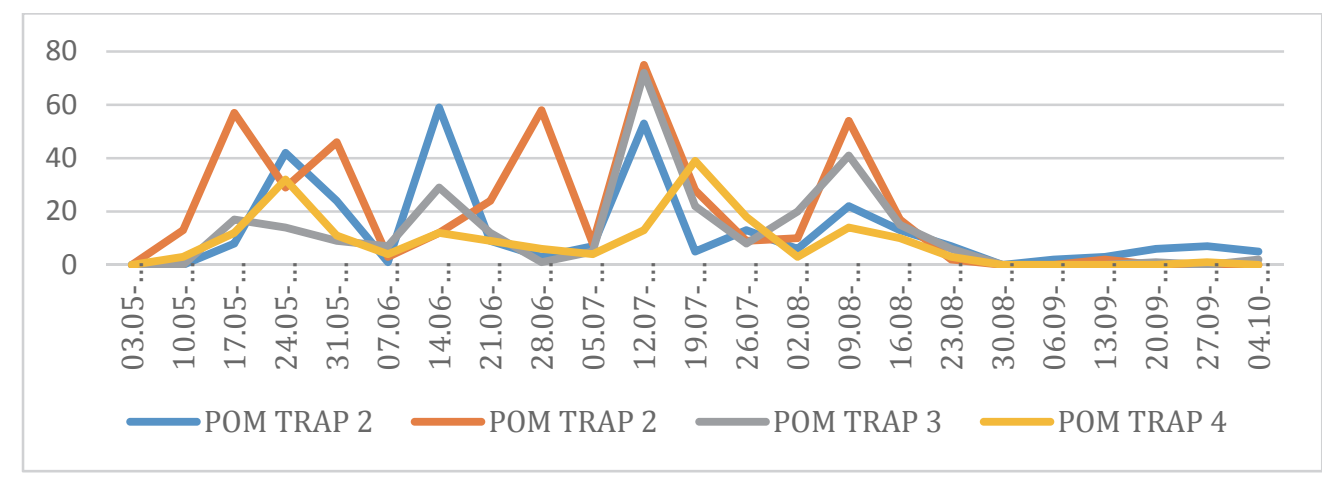

Figure 1. The flight curve of C. pomonella in 2021 on four locations in Bistrita county.

Leucoptera scitella and Hedya nubiferana were absent from two of the locations and had a relatively small number of captured individuals, indicating low populations in the area that do not require control.

Phyllonorycter blancardella - Although it was the species with the highest number of captured individuals, it was still below the level recorded in other studies conducted in Romania and France in previous years. In 2008 in the Pitesti area the level of catches was 3652 butterflies in a treated orchard (Marin et al., 2009) while in France about 2000 individuals were caught using the same attractant in just 5 weeks (Frerot and Gallois, 1979). This shows that despite the high values compared to the other lepidoptera caught by us, the population density in the Bistrita area is not very high.

Spilonota ocellana also displayed a low number of individuals but it was present in all four locations suggesting that this species is present in a large area in Bistrita-Nasaud County even in location 4 . The climatic conditions in that region are specific to the mountain area with an average annual temperature between $7-8^{\circ} \mathrm{C}$, while in the Bistrita area the average annual temperature of recent years is $9.5-10.4{ }^{\circ} \mathrm{C}$ according to the Romanian National Meteorological Administration.

Grapholita molesta and Cydia funebrana also had long flight periods from the first decade of May to the first decade of October and numerous males that were attracted to the pheromone traps indicate dens populations in this area so both of these plum pests must be taken into consideration for future control strategies. Many of the oriental moth males were also attracted to the Cydia funebrana lures so the populations could be even denser than the specific pheromone trap indicates. We must outline the fact that the substance (Z)-8dodecen-1-yl acetate is a compound used for preparing lures for both these species and is secreted by many Lepidoptera females.

The analysis of the standard deviation and the coefficient of variation (Table 2) indicate high variability in the population density between locations that could be the result of several factors such as: the biological cycle, more precisely the sequence of generations, climate variations between the time intervals when readings were made, microclimatic conditions due to sun exposition of the orchards and proximity of untreated orchards or spontaneous flora containing hosts of the studied species, etc. The influence of the lack of treatments can be excluded because none of the orchards was treated with insecticides during the summer. Also, the presence of other orchards or spontaneous flora that could be host to harmful lepidoptera is similar in all our cases. 
Table 2. Number of moths caught in the four orchards, in 2021

\begin{tabular}{|c|c|c|c|c|c|c|c|}
\hline & $\begin{array}{l}\text { Atra- } \\
\text { Pom }\end{array}$ & $\begin{array}{l}\text { Atra- } \\
\text { Fun }\end{array}$ & $\begin{array}{l}\text { Atra- } \\
\text { Mol }\end{array}$ & $\begin{array}{l}\text { Atra- } \\
\text { Blanc }\end{array}$ & $\begin{array}{l}\text { Atra- } \\
\text { Scit }\end{array}$ & $\begin{array}{l}\text { Atra- } \\
\text { Ocellan }\end{array}$ & $\begin{array}{l}\text { Atra- } \\
\text { Nub }\end{array}$ \\
\hline Orchard 1 & 295 & 149 & 404 & 1167 & 106 & 47 & 0 \\
\hline Orchard 2 & 447 & 269 & 314 & 1992 & 61 & 35 & 34 \\
\hline Orchard 3 & 281 & 131 & 340 & 1743 & 0 & 22 & 11 \\
\hline Orchard 4 & 194 & 198 & 339 & 287 & 0 & 11 & 0 \\
\hline MEAN & 304,3 & 186,7 & 349,2 & 1297,2 & 41,7 & 28,7 & 11,2 \\
\hline $\begin{array}{c}\text { Standard } \\
\text { deviation }\end{array}$ & 91,04 & 53,4 & 33,3 & 655,5 & 44,7 & 13,5 & 13,8 \\
\hline $\begin{array}{c}\text { Coef. of variation } \\
\text { (\%) }\end{array}$ & 334.17 & 349.44 & 1049.37 & 197.89 & 93.44 & 212.42 & 81.04 \\
\hline Range & 253 & 138 & 90 & 1705 & 106 & 36 & 34 \\
\hline
\end{tabular}

Given the high values of the coefficients of variation calculated for all the species of lepidoptera studied and especially for the species whose larvae attack the fruit and the availability of meteorological date for the locations 1, 2 and 3, we wanted to determine if there is a correlation between the number of males caught and climatic conditions. We analyzed statistically the data obtained for the pest species whose population would need control because the catches were frequently above the economic damage threshold, these being: $C$. pomonella and P. blancardella in the case of apple and G. molesta and C. funebrana in the case of the plum. The analysis was made for the three orchards that are located in similar geographical areas. We found that the average value for apple-specific pests was 987.5, and for plum-specific pests 268.0. The value registered for the apple species was higher than the one registered for the plum species, 3.69 times the difference being significant.

Analysing the number of males captured for each of the 2 apple pests, we found that the average number of males in Phyllonorycter blancardella was 1634 and in Cydia pomonella 341. This value recorded in the pest $P$. blancardella was higher than that recorded in the pest $C$. pomonella fold 4.8 times, the difference being distinctly statistically significant. Analyzing the same situation in the plum species, we found that the number of males caught in the case of the pest Grapholita molesta was higher than that recorded in the case of the pest Cydia funebrana fold 1.93 times, but the difference was statistically insignificant.

Taking into account the above, we consider that in the case of both apple and plum orchards it can be recommended to adopt organic control strategies using pheromones because both the number of individuals captured and the specificity of the attractants used are favorable arguments for this type of control

We analyzed the catches of adult moths of species Cydia pomonella, Phyllonoricter blancardella, Spilonota ocellana, Grapholita molesta and Cydia funebrana from the three locations within the range of the Bistrita meteorological station in correlation with meteorological data. The species chosen were those in which there were catches in all three locations. Correlation coefficients were calculated between catches grouped on seven-days intervals and average climate data from the same intervals. The results revealed differences between the way in which the average and minimum temperature, on one hand, and the average and maximum humidity, respectively the precipitations, influence the capture of the different species of pests (Table 3). Our results confirm the assumption that temperature is the factor with the greatest influence on the capture by pheromone traps of adult Lepidoptera. A positive moderate correlation can be observed between the average 
temperature and the number of adults captured for P. blancardella, C. funebrana and $S$. ocellana. P. blancardella number of males caught also moderately correlate with the minimum temperature, the bigger the temperature the higher the number of individuals caught on the sticky traps. All the other species had a weak but positive correlation with the average and minimum temperatures.

Table 3. The coefficient of correlation ( $\mathrm{r}$ ) between the average number of captured male adults and meteorological parameters for the interval 03.05-12.09.2021

\begin{tabular}{|l|c|c|c|c|c|}
\hline \multirow{2}{*}{$\begin{array}{l}\text { Meteorological } \\
\text { parameter }\end{array}$} & \multicolumn{6}{|c|}{ Name of the species } \\
\cline { 2 - 6 } & Cydia $p$. & Spilonota $o$. & Phyllonoricter $b$. & Grapholita $m$. & Cydia f. \\
\hline $\begin{array}{l}\text { Average } \\
\text { temperature }\end{array}$ & $\begin{array}{r}0.381651 \\
++\end{array}$ & $\begin{array}{r}0.441971 \\
++\end{array}$ & $\begin{array}{r}0.574042 \\
++\end{array}$ & $\begin{array}{r}0.244008 \\
+\end{array}$ & $\begin{array}{r}0.405994 \\
++\end{array}$ \\
\hline $\begin{array}{l}\text { Minimum } \\
\text { temperature }\end{array}$ & $\begin{array}{r}0.305421 \\
+\end{array}$ & $\begin{array}{r}0.374621 \\
++\end{array}$ & $\begin{array}{r}0.614341 \\
++\end{array}$ & 0.219227 & $\begin{array}{c}0.337282 \\
+\end{array}$ \\
\hline $\begin{array}{l}\text { Number of } \\
\text { rainy days }\end{array}$ & -0.15403 & -0.07209 & -0.314920 & 0.002606 & 0.179273 \\
\hline $\begin{array}{l}\text { Maximum } \\
\text { humidity }\end{array}$ & -0.19924 & 0.0086 & -0.245530 & 0.039194 & 0.159742 \\
\hline $\begin{array}{l}\text { Average } \\
\text { humidity }\end{array}$ & -0.3572200 & -0.213130 & -0.17582 & 0.03129 & -0.11211 \\
\hline $\begin{array}{l}\text { The amount of } \\
\text { precipitation }\end{array}$ & -0.277080 & -0.04028 & -0.17531 & -0.00778 & 0.103271 \\
\hline
\end{tabular}

In the case of humidity and precipitation, the correlation with the number of insects captured is either non-existent or weak and mostly negative. In conclusion, the influence of these parameters is much smaller than that of temperature, as other authors have concluded (Paulen and Kobolka, 2018). The highest correlation was between the average humidity and C. pomonella $\mathrm{r}=-0.35722$ as well as between rainfall and C. pomonella $\mathrm{r}=-0.27708$ showing a weak negative influence on the number of moths captured (Figure 2).
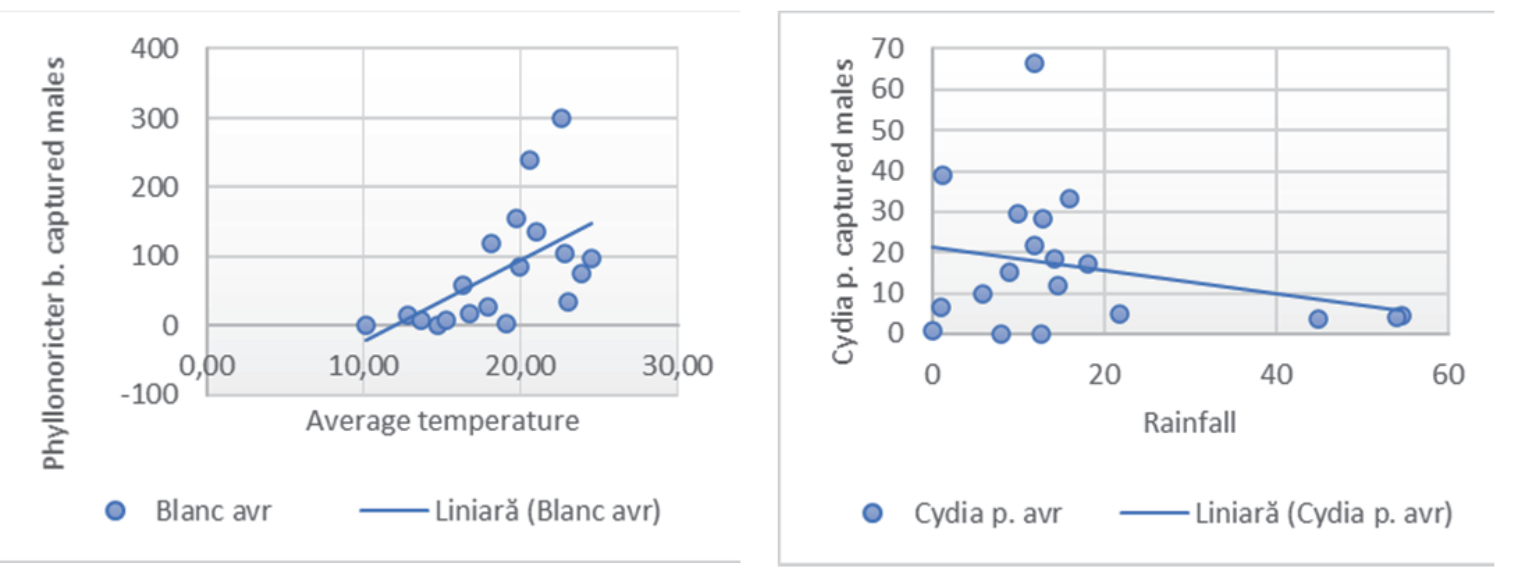

Figure 2. The correlation between the average temperature and the number of adults of $P$. blancardella captured (left) and the correlation between the rainfall and the catches of $C$. pomonella (right), May-September 2021.

\section{CONCLUSIONS}

The present study showed significant variation in the presence and population density of harmful species of Lepidoptera in apple and plum orchards in Bistrita county. Our data 
confirm some of the previous known facts about the flight patterns of Cydia pomonella, Phyllonorycter blancardella, Leucoptera scitella, Cydia funebrana and Grapholita molesta and also indicate that defoliators such as Hedya nubiferana and Spilonota ocellana are a part of the entomophauna of most of the Bistrita orchards. We expect to confront a rise in the density of their population if adequate control strategies will not be used in the following years.

Temperature is the climatic factor with the greatest share in the influence that environmental factors exert on the capture of harmful lepidoptera with the help of pheromone traps.

We can conclude that although there are significant differences between the number of harmful individuals belonging to the genus Lepidopterae caught in apple and plum orchards, it is advisable to introduce control by using pheromones because the population density is quite high in the case of the main pests of the two fruit species.

\section{ACKNOWLEDGEMENTS}

The study is part of the project "Ecotechniques of orchard pest control for organic fruits in operational group ECO_FRUCT_BN" founded by the European Union and Romanian Government through the contract PNDR-AFIR 161A0000011860600004.

\section{REFERENCES}

1.Arn, H., Delley, B., Baggiolini, M., and Charmillo, P.J. (1976). Communication disruption with sex attractant for control of the plum fruit moth, Grapholitha funebrana: a two-year field study. Entomologia Experimentalis et Applicata 19: 139-147.

2.Beroza, M., Gentry, C.R., Blythe, J.L., and Muschik, G.M. (1973). Isomer content and other factors influencing captures of oriental fruit moth by synthetic pheromone traps. Journal Economic Entomology 66: 13071311.

3.Buser, H.R., and Arn H. (1975). Analysis of insect pheromones by quadrupole mass fragmentography and highresolution gas chromatography. Journal of Chromatography 106(1): 83-95.

4.Ciocan-Tarta, I., Oprean, I., Ghizdavu, I., and Pojar-Fenesan, M. (1998). Exo- and endohormones. XVII - Synthesis of racemic 5,9-dimethyl-heptadecane, the sex pheromone for the leafminer moth Leucoptera scitella. Revue Roumaine de Chimie 43(3): 215-219,

5.Ciotlăuş, I., Gânscă, L., Andreica, A., and Oprean, I. (2017). A practical synthesis of (Z)-and (E)-8-Dodecene-1-yl acetate, components of Lepidoptera insect sex pheromones. Revista de chimie 68(1): 157-162.

6.Francke, W., Franke, S., Tóth, M., Szöcs, G., Guerin, P., and Arn, H. (1987). Identification of 5,9dimethylheptadecane as a sex pheromone of the moth Leucoptera scitella. Naturwissenschaften 74:143144.

7.Frérot, B., Priesner, E., and Gallois, M. (1979). A sex attractant for the green budworm moth, Hedya nubiferana. Zeitschrift für Naturforschung C. 34: 1248-1252

8.Gânscă, L., and Oprean, I. (2001). Exo- and endohormones XIX, "Synthesis of Z- 10-Dodecen-1-yl Acetate, component of some Lepidopteran insect sex pheromones". Revue Roumaine de Chimie 46(7): 763-765

9.Ghizdavu, I., Oprean, I., Bodiș, I., Ghizdavu, L., and Ginsca, L. (1987). Research to combat of the Spotted Dentiform Leaf Moth Phyllonorycter blancardella F. by male mass trapping using pheromonal traps Bulletin of Institute of Agronomy Cluj-Napoca A-41: 95-98.

10.Granges, J., and Baggiolini, M. (1971). A synthetic sex-attractant pheromone for the plum moth (Grapholitha funebrana Tr. (Lep. Tortricidae)). Revue. Suisse Viticulture et Arboriculture 3: 93-94.

11.Koutinkova, H., Andreev, R., Subchev, M., Toth, M., and Szocs, G. (1999). Monitoring of the leafminer Leucoptera scitella Zell (Lepidoptera: Lyonetidae) by pheromone traps in Bulgaria. Acta Phytopathologica et Entomologica Hungarica 34(4): 327-331.

12.Maciesiak, A. (1999). Pear leaf blister moth (Leucoptera scitella Zell.) appearance and control. Progress in Plant Protection 39(2):444-447.

13.Marin F.C., Sumedrea M., Sumedrea D., Călinescu M., Tanasescu N. and Smaranda Şt. (2009). Phytoprotection technologies for new promoted apple cultivars. Research Journal of Agricultural Science 41: 84-89.

14.McBrien, H.L., Gries, G., Gries, R., Borden, J.H., Judd, G.J.R., King, G.G.S., and Slessor, K.N. (1992). Sex pheromone components of the eyespotted bud moth, Spilonota ocellana (Denis and Schiffermüller) (Lepidoptera: Olethreutidae). The Canadian Entomologist 124:1391-1394. 
15.Mozûraiti,s R., Borg Karlson, A.K., Bûda, V., and Ivinskis, P. (1999b). Sex pheromone of the spotted tentiform leafminer moth Phyllonorycter blancardella (Fabr.) (Lep., Gracillariidae). Journal of Applied Entomology 123: 603-606.

16.Paulen, O. and Kobolka, R. (2018) Monitoring of moth pests in apple tree orchard. Acta Horticulturae and Regioculturae 2: 54-57.

17.Roelofs ,W.L., and Brown, R.L. (1982a). Pheromones and evolutionary relationships of Tortricidae. Annual Review of Ecology and Systematics 13: 395-422

18.Roelofs, W.L., Comeau, A., and Selle, R. (1969b). Sex pheromone of the oriental fruit moth. Nature. 224: 723727

19.Roelofs, W.L., Reissig, W.H., and Weires, R.W. (1977c). Sex attractant for the spotted tentiform leaf miner moth, Lithocolletis blancardella. Environmental Entomology 6: 373-374

20.Rosu-Mares, S., Sofron, A., and Moldovan, C. (2020). Preliminary results on the changes in the flight dynamic of Cydia pomonella (L.) In North-Eastern Transylvania, under the influence of climate change. Scientific Papers. Series B, HorticultureLXIV(1): 183-185.

21.Sjoberg, P., Ramert, B., Thierfelder, T., and Hillbur, Y. (2015). Ban of a broad-spectrum insecticide in apple orchards: effects on tortricid populations, management strategies, and fruit damage. Journal of Pest Science 88(4): 767-775.

22.Smirle, M.J., Vincent, C., and Zurovski, C.L. (1998). Azinphosmethyl resistance in the Obliquebanded Leafroller, Choristoneura rosaceana: reversion in absence of selection and relationship to detoxication enzyme activity. Pesticide Biochemistry and Physiology 61:183-189.

23.Sumedrea, M., Marin, F.C., Calinescu, M., Sumedrea D. and Iorgu, A., (2015) Researches regarding the use of mating disruption pheromones in control of apple codling moth - Cydia pomonella L. Agriculture and Agricultural Science Procedia 6:171-178

24.Vasian, I., Tötös, S., and Oprean, I. (2013). A new synthesis of (E)-10-Dodecenyl Acetate the major sex pheromonal component of Phyllonorycter blancardella. Revista de chimie 64(2):158-160. 